\title{
Systemic effector and regulatory immune responses to chlamydial antigens in trachomatous trichiasis
}

\section{Alevtina Gall' ${ }^{1}$ Amir Horowitz ${ }^{2}$, Hassan Joof ${ }^{1}$, Angels Natividad ${ }^{3}$, Kevin Tetteh ${ }^{4}$, Eleanor Riley ${ }^{2}$, Robin L. Bailey ${ }^{3}$, David C. W. Mabey ${ }^{3}$ and Martin J. Holland ${ }^{1,3 *}$}

Viral Diseases Programme, Medical Research Council Laboratories, Banjul, The Gambia

2 Department of Immunology and Infection, London School of Hygiene and Tropical Medicine, London, UK

${ }^{3}$ Department of Clinical Research, London School of Hygiene and Tropical Medicine, London, UK

4 Department of Pathogen Molecular Biology, London School of Hygiene and Tropical Medicine, London, UK

\section{Edited by:}

Rey Carabeo, Imperial College

London, UK

\section{Reviewed by:}

Kathleen Kelly, University of California

at Los Angeles, USA

Toni Darville, University of Pittsburgh

Medical Center, USA

*Correspondence:

Martin J. Holland, Department of Clinical Research, London School of Hygiene and Tropical Medicine, London WC1E 7HT, UK

e-mail:martin.holland@Ishtm.ac.uk
Trachomatous trichiasis (TT) caused by repeated or chronic ocular infection with Chlamydia trachomatis is the result of a pro-fibrotic ocular immune response. At the conjunctiva, the increased expression of both inflammatory (IL1B, TNF) and regulatory cytokines (IL10) have been associated with adverse clinical outcomes. We measured in vitro immune responses of peripheral blood to a number of chlamydial antigens. Peripheral blood effector cells (CD4, CD69, IFN $\gamma$, IL-10) and regulatory cells (CD4, CD25, FOXP3, CTLA4/GITR) were readily stimulated by $C$. trachomatis antigens but neither the magnitude (frequency or stimulation index) or the breadth and amount of cytokines produced in vitro [IL-5, IL-10, IL-12 (p70), IL-13, IFN $\gamma$, andTNF $\alpha$ ] were significantly different between TT cases and their non-diseased controls. Interestingly we observed that CD4+T cells account for $<50 \%$ of the IFN $\gamma$ positive cells induced following stimulation. Further investigation in individuals selected from communities where exposure to ocular infection with $C$. trachomatis is endemic indicated that CD3-CD56+ (classical natural killer cells) were a major early source of IFN $\gamma$ production in response to $C$. trachomatis elementary body stimulation and that the magnitude of this response increased with age. Future efforts to unravel the contribution of the adaptive immune response to conjunctival fibrosis should focus on the early events following infection and the interaction with innate immune mediated mechanisms of inflammation in the conjunctiva.

Keywords: Chlamydia trachomatis, trachoma, immune response, Tregs, NK cells, interferon-gamma

\section{INTRODUCTION}

Chlamydia trachomatis is the leading infectious cause of blindness worldwide. Persistent infection or recurrent infection with C. trachomatis, can stimulate a fibrotic immune response that leads to deposition of scar tissue on the upper tarsal conjunctiva and the development of a dry eye syndrome. The progressive development of scar tissue can lead to entropion and trachomatous trichiasis (TT), which if left untreated may result in damage to the cornea causing opacity, low vision, and blindness (Mabey et al., 2003). There are an estimated eight million individuals currently suffering from TT with about 1.3 million irreversibly blind as a result (Mariotti et al., 2009).

Chlamydia trachomatis is also the most common bacterial sexually transmitted infection. It is frequently asymptomatic, especially in women and can lead to sub-fertility, chronic pelvic inflammatory disease, ectopic pregnancy, and sterility (WHO, 2007). Although both ocular and genital chlamydial infections are treatable with antibiotics, persistent, and recurring infection is common. A licensed vaccine against $C$. trachomatis for use in the human population is not yet available despite continued efforts since the 1960s. Recent developments (reviewed by Rockey et al., 2009) have yielded encouraging results in some animal models; however, the development of an effective vaccine requires further understanding of the basic features of the human immune response to $C$. trachomatis infection. Indeed work in mice has suggested that chlamydial vaccine induced immunity without pathology can be achieved and this is distinct from immunity induced by infection that results in pathology (Igietseme et al., 2009). However in naturally exposed populations only a minority develops the pathological sequelae of infection, suggesting that the immunological features of naturally immune individuals may be equally distinct.

In animal models of infection it is well established that CD4+ T helper type 1 (Th1) cells are essential for the clearance of primary chlamydial infection (Igietseme et al., 2009). In particular, IFN $\gamma$ plays an important role in the clearance of chlamydial infection. In mice and in humans its production is associated with protection from re-infection (Wang et al., 1999; Cohen et al., 2005). However, uncontrolled inflammatory responses, in part driven by IFN $\gamma$ production, result in pathology. Regulatory T cells (Tregs), induction of regulatory cytokines such as IL-10 or the activation of type 2 (Th2) responses counteract the inflammatory environment and contribute to restoring homeostasis (Yang et al., 1999; Wang et al., 2005). Conversely unchecked type 2 responses are frequently associated with chronic inflammation and infection (Wynn, 2004) and hampering Th2 responses have been implicated in chlamydial infections and induced disease (Holland et al., 1993, 1996; Gondek et al., 2009). In addition some immune mediated fibrotic diseases, such as schistosomula induced hepatic fibrosis, 
are also dominated by Th2-cytokine responses (Chiaramonte et al., 2003). The pathogenic changes observed at the site of infection in chlamydial genital and ocular disease are also due to development of fibrotic tissue yet convincing evidence of a significant role for polar CD4+ Th2 responses or alternative macrophage activation are lacking (Holland et al., 2010; Natividad et al., 2010). Many groups have now demonstrated the important role of immunoregulatory subsets of CD4+ T cells in preventing immune damage during viral, bacterial, and parasitic infections, and specifically in persistent infections at mucosal surfaces (Maloy and Powrie, 2001; Belkaid and Tarbell, 2009) but these have not been extensively studied in human chlamydial disease.

One subset of CD4+ T cells that has key functions in immune homeostasis are Tregs (CD4+CD25+FOXP3+). The regulatory function of these natural and adaptive Tregs may be mediated by production of TGF- $\beta$ and IL-10 or by cognate interaction (Hori et al., 2003; Fontenot et al., 2005). Antigen-specific IL-10 secreting type-1 T regulatory cells $\left(\mathrm{T}_{\mathrm{R}} 1\right)$ which do not express FOXP3 have also been described in vivo following chronic antigenic stimulation (Vieira et al., 2004), and develop in parallel with Th1 cells in several chronic infectious diseases (McGuirk et al., 2002). Murine studies have established that FOXP3 + regulatory cells can secrete both IFN $\gamma$ and IL-10 (Stock et al., 2004) and in humans regulatory function can also be exerted via perforin dependent lysis (Grossman et al., 2004). Thus, although most work has focused on cells with a classic Treg phenotype (CD4+CD25+FOXP3+), cells from CD4+CD25-, $\mathrm{CD} 8+$, and NKT subsets can all exert regulatory function (Jiang and Chess, 2004). There is also evidence that CD4+ Th1 cells can exhibit self-regulatory properties and cytokine profiles, obviating the need to explain disease in terms of a separate regulatory class of T cells (Anderson et al., 2007; Jankovic et al., 2007).

We have previously demonstrated a relative Chlamydia-specific hypo-responsiveness associated with chronic ocular infection (Holland et al., 1993; Bailey et al., 1995), and described imbalances in antigen-specific secretion of both IL-10 and IFN $\gamma$ in cultured peripheral blood mononuclear cell (PBMC) from scarred subjects (Holland et al., 1996). We have also found that IFN $\gamma$, IL-10, and perforin expression in the conjunctiva is associated with the clinical signs of active trachoma (Burton et al., 2004); that susceptibility to scarring sequelae is affected by haplotypic variation at the IL-10 locus (Natividad et al., 2005, 2008), that contributes to variation in IL-10 expression; and that the expression of FOXP3 is up-regulated in individuals who have recently resolved ocular C. trachomatis infection (Faal et al., 2006).

In animal models of viral ocular infection, several groups have identified an important role for Tregs in modulating the severity of disease (Suvas et al., 2004; Nesburn et al., 2007). Aside from FOXP3, other potential makers of regulatory $\mathrm{T}$ cells have been identified in the search to phenotypically define Tregs. Most commonly the relative expression of the IL-7 receptor (CD127) is used as a fourth surface marker (Finney et al., 2010), the low expression of which is regarded as further evidence of Tregs. Two other common markers with demonstrated independent down regulatory properties are Cytotoxic T Lymphocyte Antigen 4 (CTLA4) and Glucocorticoidinduced tumor necrosis factor-receptor related protein (GITR) both of which have been linked to the suppressive mechanism of Tregs (Zheng et al., 2004; Nocentini and Riccardi, 2005). Moreover, in rabbits with ocular HSV infection, cells in the conjunctiva, which expressed high levels of FOXP3, GITR, and CTLA4, were effectively able to suppress the effector function of HSV-specific CD4+ and CD8+ T cells (Nesburn et al., 2007).

In this study we compared the in vitro immune responses of individuals with TT and controls with normal eyes from trachoma endemic communities, since we expected that immune responses from these individuals would be the most polar. We investigated the immune responsiveness of several chlamydial antigens that had not previously been measured in individuals from trachoma endemic communities. Cytokine levels in supernatants from proliferation assays were quantified for IL-5, IL-10, IL-12p70, IL-13, IFN $\gamma$, and TNF $\alpha$. Immune responses were also assessed using flow cytometry, where cells were stained for IFN $\gamma$ and IL-10, as well as Treg cell markers FOXP3, CTLA4, and GITR. To investigate which cells were the major sources of IFN $\gamma$, we further stained for markers that included CD8 and CD3-CD56+ cells in PBMC isolated from young and adult individuals from the same trachoma endemic environment.

\section{MATERIALS AND METHODS STUDY PARTICIPANTS}

Informed consent was obtained from all study participants. Participants were recruited from rural and semi-urban areas within the Western Region and the Lower river regions (LRR) of The Gambia. Trachoma was graded using the WHO simplified grading system by a single experienced field supervisor. Forty-two subjects with TT (more than one eyelash touching the globe of the eye) were identified. For each TT case an age, sex, and location matched control subject with normal eyes that was not a member of the same family was also recruited. Participants were age matched within 10 years. In a standardized manner, an ocular swab from the everted tarsal conjunctiva of each participant was collected into RNAlater ${ }^{\circledR}$ (Ambion Ltd) for the later isolation of proteins and nucleic acids. For the in vitro study of natural killer (NK) cell responsiveness, five healthy participants from three different age groups $(2-5 ; 15-25 ;>35$ years) from trachoma endemic communities in the West Kiang District of LRR were recruited. Historical exposure to ocular infection in these districts was expected to be high since structured surveys as part of a national trachoma control program identified this district as requiring mass drug treatment. As a result, these communities were treated with three annual rounds of oral azithromycin, completed in 2009 as per WHO guidelines for community control strategies. The joint Scientific and Ethics Committee of the Gambian government and the Medical Research Council Laboratories approved each study (applications L2006.10 and SCC1201). In addition the ethics committee of the LSHTM also approved the studies. All study participants outside of community trachoma control programs were offered treatment according to national eye care program guidelines.

\section{PROLIFERATION ASSAYS}

Venous blood $(20 \mathrm{ml})$ was collected into tubes containing 300 units of sterile, preservative-free sodium heparin. After the removal of $2.5 \mathrm{ml}$ of blood for whole blood cultures the PBMCs were isolated from the remaining blood by centrifugation over Lymphoprep (Axis-Shield Ltd, Kimbolton, UK) as described previously (Holland et al., 1996). 
Plasma was harvested by collection from above the PBMC layer and stored at $-30^{\circ} \mathrm{C}$ for later use in enzyme-linked immunosorbent assays (ELISA) to estimate the anti-chlamydial antibody titer. PBMCs were co-incubated for 7 days with $5 \mu \mathrm{g} / \mathrm{ml}$ of each antigen (Pokeweed mitogen, PWM; Purified protein derivative, PPD) of Mycobacterium tuberculosis strain Rv37 and the following C. trachomatis antigens; Serovar A (strain SA1) elementary bodies (EBs), major outer membrane protein (MOMP), Enolase, polymorphic outer membrane protein (Pmp) D, PmpG, outer membrane protein (Omp) 2. On day six, $100 \mu \mathrm{l}$ of culture supernatant was removed from each well without disturbing the cell pellet and $1 \mu \mathrm{Ci} /$ well ${ }^{3} \mathrm{H}$-thymidine added for the last $18 \mathrm{~h}$ of culture. The culture supernatant was frozen at $-30^{\circ} \mathrm{C}$ until tested by multiplex bead array for cytokines. ${ }^{3} \mathrm{H}$-thymidine incorporation was estimated using liquid scintillation counting (Micro-beta, Wallac, Turku, Finland). Results were expressed as $\log _{10}$ stimulation indices (SI), which were calculated as described by Bennett and Riley (1992) using the geometric mean of the triplicate counts per minute (CPM) for the test antigen/CPM (geometric mean) of triplicate wells that only received cells and RPMI.

\section{CYTOKINE DETECTION}

The triplicate wells of day six supernatants from microtiter plates were pooled and $25 \mu \mathrm{l}$ used in a six-plex (IL-5, IL-10, IL-12p70, IL-13, IFN $\gamma$, and TNF $\alpha$ ) cytokine assay (Bio-Rad, United Kingdom) according to the manufacturer's instructions. The plates were then read using a Bio-plex instrument (Bio-Rad, UK). Unknown samples were quantified by reading standard curves prepared for each of the cytokines under study. Lower and upper limits of detection were dependent on assay performance. Any samples with cytokine levels that were outside of the working range of each assay were reported as under or over the detection limit and for the purposes of analysis were given a value equal to the minimum or maximum detectable level.

\section{ANTIBODY STAINING AND FACS ANALYSIS}

Five hundred microliters of whole blood was co-stimulated with $10 \mu \mathrm{g} / \mathrm{ml}$ of FastImmune ${ }^{\mathrm{TM}}$ [CD28/CD49d co-stimulatory reagent (BD Biosciences)] and incubated with $5 \mu \mathrm{g} / \mathrm{ml}$ of whole Ct EB or Staphylococcus aureus Enterotoxin B (SEB) for 48 h. Cultures stimulated with FastImmune ${ }^{\mathrm{TM}}$ alone served as controls. BD GolgiPlug ${ }^{\mathrm{TM}}$ (Brefeldin A; BD Biosciences) was added for the last $18 \mathrm{~h}$ of culture at $1 \mu \mathrm{g} / \mathrm{ml}$. Cells were harvested by centrifugation followed by lysis of red blood cells and further washing in serum free RPMI by centrifugation. When required, PBMC were permeabilized for intracellular staining. The following antibodies were used: CD4-PerCP (SK3), CD25-FITC (M-A251), IFN $\gamma$-FITC (4S.B3), IL-10-PE (JES319F1) and CTLA4-PE (BNI3) CD69-APC (FN50; BD Pharmingen), FOXP3-APC (PCH101; eBiosciences), and GITR-PE (110416; R\&D Systems). Samples were then examined using a FACS Caliber flow cytometer (Becton, Dickinson and Company, NJ, USA) and the data collected using CellQuest-Pro. Files were further analyzed using FlowJo software (Treestar, OR, USA).

\section{CELL SURFACE AND INTRACELLULAR STAINING FOR NK CELLS}

Surface and intracellular staining was performed as described previously (Horowitz et al., 2010a,b). Briefly $4 \times 10^{5}$ PBMC were incubated for $24 \mathrm{~h}$ with $10 \mu \mathrm{g} / \mathrm{ml} \mathrm{EBs.} \mathrm{As} \mathrm{a} \mathrm{positive} \mathrm{control} \mathrm{rIL-12/IL-18}$ were added to separate cultures. Abs used were as follows: CD69 PE (CH/4; BD Pharmingen), CD56 PE (N901), CD56 APC (N901; both Beckman Coulter, Fullerton, CA, USA), CD56 PE-Cy7 (B159), CD3-PerCP (SK7), CD4 APC-Cy7 (RPA-T4), CD4 PE (RPA-T4), CD8 PE (SK1), CD3 PE-Texas Red (S4.1) CD107a (LAMP-1) biotin (H4A3; Caltag/Invitrogen), CD8 Pacific Blue (LT8; eBiosciences, San Diego, CA, USA), and IFN $\gamma$ FITC (D9D10; Ab Serotec). For CD107a staining antibody and GolgiPlug ${ }^{\mathrm{TM}}$ were added to the cultures for the last $4 \mathrm{~h}$ of stimulation when they were washed and permeabilized. The remaining cocktail of antibodies was then added staining both surface and intracellular antigens. Samples were then examined using a Dakocytomation CyAn flow cytometer (Beckman Coulter, Fullerton, CA, USA) and the data collected using Summit FCS 4.3 software. Files were further analyzed using FlowJo (Treestar, OR, USA).

\section{ISOLATION OF DNA FROM OCULAR SWABS}

DNA was isolated from ocular swabs using Qiagen RNeasy micro kits and DNA mini kits as described elsewhere (Holland et al., 2010). The presence of C. trachomatis was then tested using CT/ NG by Amplicor (Roche) as described previously (Holland et al., 2010). Sample integrity and quality for each ocular swab was confirmed by performing PCR on genomic DNA using primers for human-specific hypervariable 1 (HV1) D-loop region mitochondrial DNA as described previously (Harding-Esch et al., 2009a).

\section{SEROLOGY}

Plasma antibody titrations were performed using purified serovar A EBs immobilized on ELISA microtiter plates as described previously (Wang et al., 2009, 2010).

\section{STATISTICAL ANALYSIS}

Statistical analysis was performed using the statistical analysis tool in GraphPad Prism 5 software (GraphPad Software, Inc, La Jolla, CA, USA). A paired Student's $t$-test was used for combined data of cases and controls when compared to background controls. When comparing the response of matched cases and controls an adaptation of the Mann-Whitney distribution-free paired test was used (Wilcoxon signed rank). For the simultaneous comparison of three age groups we used a non-parametric ANOVA (GraphPad Prism) which is a omnibus Kruskal-Wallis test progressing to post hoc testing of simultaneous pairwise comparisons using Dunn's Test if the overall $P$-value $<0.05$. Both Kruskal-Wallis and Dunn's Test are distribution-free tests of significance.

\section{RESULTS \\ STUDY PARTICIPANTS}

The basic study participant details from each section of the study are described in Table 1. Forty-two case-control pairs were used in the lymphocyte proliferation assays. Up to 17 of these case-control pairs were studied using FACS analysis and multiplex bead arrays for cytokines. Approximately $2 / 3$ of the case-control pairs were from females (27/42) and the median age was 58 years. All ocular swabs for these samples were positive for human mitochondrial DNA and negative by CT/NG Amplicor for current ocular infection 
Table 1 | Study participant demographics and Ct antibody titers.

\begin{tabular}{|c|c|c|c|}
\hline \multicolumn{4}{|l|}{ PBMC PROLIFERATION SAMPLES } \\
\hline & \multicolumn{2}{|l|}{ Cases $(n=42)$} & Controls $(n=42)$ \\
\hline Age (range) in years & \multicolumn{2}{|l|}{$60(30-85)$} & $57(30-80)$ \\
\hline \multicolumn{4}{|l|}{ Sex } \\
\hline Male & \multicolumn{2}{|l|}{15} & 15 \\
\hline Female & \multicolumn{2}{|l|}{27} & 27 \\
\hline Anti-Ct (serovar A) antibody titer & \multicolumn{2}{|l|}{$1 \times 10^{4}\left(<1 \times 10^{3}-2 \times 10^{4}\right)$} & $7.5 \times 10^{3}$ \\
\hline \multicolumn{4}{|l|}{ FLOW CYTOMETRY AND BIO-PLEX } \\
\hline & \multicolumn{2}{|l|}{ Cases $(n=17)$} & Controls $(n=17)$ \\
\hline Age (range) in years & \multicolumn{2}{|l|}{$58(35-70)$} & $54(31-75)$ \\
\hline \multicolumn{4}{|l|}{ Sex } \\
\hline Male & \multicolumn{2}{|l|}{6} & 6 \\
\hline \multicolumn{4}{|l|}{ NK PBMC FLOW CYTOMETRY } \\
\hline & $<5$ years $(n=5)$ & $<25$ years $(n=5)$ & $>35$ years $(n=5)$ \\
\hline Age (range) & $3(2-5)$ & $17(16-25)$ & $67(37-72)$ \\
\hline \multicolumn{4}{|l|}{ Sex } \\
\hline Male & 3 & 3 & 2 \\
\hline Female & 2 & 2 & 3 \\
\hline Anti-Ct (serovar A) antibody titer & $1 \times 10^{3}$ & $1 \times 10^{3}\left(<1 \times 10^{3}-2 \times 10^{4}\right)$ & $1 \times 10^{4}\left(<1 \times 10^{3}-2 \times 10^{4}\right)$ \\
\hline No. with clinical signs & 0 & 0 & 0 \\
\hline No. seropositive & 2 & 5 & 5 \\
\hline CT/NG Amplicor ( $n=$ no. positive) & n.t. & n.t. & n.t. \\
\hline
\end{tabular}

with C. trachomatis. Plasma anti-C. trachomatis antibody levels were not significantly different between the clinical groups and all sera were positive compared to plasma from immunologically naïve individuals.

\section{LYMPHOCYTE PROLIFERATIVE RESPONSES TO C. TRACHOMATIS ANTIGENS}

To determine whether the proliferative response of TT cases differed from that of the controls we studied the responses to chlamydial EBs and five recombinant antigens (Table 2). PWM was used as a positive control for the stimulation of T and B cells. We considered a SI > 2 as a significant proliferative response. Enolase, PmpD, PmpG, and Omp2, induced a pathogen-specific proliferative response that was above background and comparable to proliferation induced by stimulation with EBs. In general and as a trend, responses were higher in cases compared to controls; however, no statistically significant differences were found between TT cases and controls (Figure 1).

\section{STIMULATION OF CYTOKINE RESPONSES BY C. TRACHOMATIS ANTIGENS}

Day six supernatants from proliferation assays were collected and assessed for the presence of IL-5, IL-10, IL-12p70, IL-13, IFN $\gamma$, and TNF $\alpha$ cytokines. All antigens tested were able to elicit an IL-10, IL-12p70, IFN $\gamma$, and TNF $\alpha$ cytokine response that was significantly above background. Few antigens, however, were able to stimulate
IL-5 or IL-13 production. The levels of antigen-specific cytokine production are summarized in Figure 2. EB stimulated responses were significantly above background for IL-10, IFN $\gamma$, and TNF $\alpha$ in both TT cases and controls. However, these cytokine profiles did not correlate with disease status (Figure 2). Taken together the cytokine and proliferation data show that peripheral blood proliferative responses and cytokine production profiles are not significantly different between participants with and without TT.

\section{CD4+CD25+FOXP3+ CELLS ARE INCREASED FOLLOWING STIMULATION WITH C. TRACHOMATIS ANTIGENS}

We investigated whether immune responses of TT patients differ in regulatory phenotypic markers when stimulated by chlamydial antigens compared to their respective controls. Whole blood from 17 case-control pairs $(n=34)$ was stimulated with $C$. trachomatis EBs for $48 \mathrm{~h}$ and stained with antibodies which in combination identify Tregs (CD4+CD25+FOXP3+). FOXP3+ cells were largely contained in the $\mathrm{CD} 4+\mathrm{CD} 25+$ population, where the $\mathrm{CD} 25+$ population was continuous and no distinction was made between CD2 $5^{\text {hi }}+$ and CD $25^{\text {lo }}+$ cells. EBs were particularly effective at inducing Tregs, relative to those cells that received co-stimulation alone (Figure 3A). Figure 3B shows an example of the flow cytometry multilevel gating strategy used on each sample. CTLA4 and GITR were also used as additional surface markers of Treg activity. Stimulation with chlamydial EBs was effective in inducing the up-regulation of CTLA4 and GITR (Figure 3B). 
Table 2 | Summary of recombinant antigens used.

\begin{tabular}{|c|c|c|c|c|c|c|c|c|c|}
\hline $\begin{array}{l}\text { Serovar D } \\
\text { locus-tag } \\
\text { (NC000117) }\end{array}$ & Name & $\begin{array}{l}\text { Antigen details } \\
\text { (kDa) }\end{array}$ & $\begin{array}{l}\text { Serovar } \\
\text { origin }\end{array}$ & $\begin{array}{l}\text { DNA insert } \\
\text { fragment } \\
\text { size (bp) }\end{array}$ & $\begin{array}{l}\text { Product } \\
\text { size by } \\
\text { SDS- } \\
\text { PAGE } \\
\text { (kDa) }\end{array}$ & $\begin{array}{l}\text { Production } \\
\text { of original } \\
\text { expression } \\
\text { clone }\end{array}$ & $\begin{array}{l}\text { Fusion } \\
\text { protein } \\
\text { type }\end{array}$ & $\begin{array}{l}\text { Recombinant } \\
\text { expression and } \\
\text { purification }\end{array}$ & $\begin{array}{l}\text { Publications } \\
\text { (cellular } \\
\text { responses } \\
\text { only) }\end{array}$ \\
\hline CT812 & PmpD & $\begin{array}{l}\text { Polymorphic } \\
\text { outer membrane } \\
\text { protein } \\
\text { (polymorphic } \\
\text { family of } 9 \text { genes } \\
\text { A-l; 160) }\end{array}$ & L2 & $\begin{array}{l}2.024 \mathrm{~kb} \\
\text { (690-2714 } \\
\text { gene } \\
\text { fragment) }\end{array}$ & 74 & $\begin{array}{l}\text { Prof. Hill } \\
\text { Gaston and } \\
\text { Dr. Jane } \\
\text { Goodall, } \\
\text { University of } \\
\text { Cambridge }\end{array}$ & His-tag & pPET/ProBond® & $\begin{array}{l}\text { Goodall et al. } \\
\text { (2001b) }\end{array}$ \\
\hline CT681 & MOMP & $\begin{array}{l}\text { Major outer } \\
\text { membrane } \\
\text { protein (40) }\end{array}$ & L1 & $\begin{array}{l}1.6 \mathrm{~kb} \\
\text { (285-1182 } \\
\text { gene } \\
\text { fragment) }\end{array}$ & 33 & $\begin{array}{l}\text { Prof. lan } \\
\text { Clarke, } \\
\text { University of } \\
\text { Southampton }\end{array}$ & B-gal & $\begin{array}{l}\text { Induced } \\
\text { insoluble } \\
\text { inclusions } \\
\text { purified by } \\
\text { centrifugation } \\
\text { resuspended in } \\
\text { octylglucoside/ } \\
\text { DTT }\end{array}$ & $\begin{array}{l}\text { Holland et al. } \\
\text { (1993) }\end{array}$ \\
\hline СТ871 & PmpG & $\begin{array}{l}\text { Polymorphic } \\
\text { outer membrane } \\
\text { protein (107) }\end{array}$ & A & $\begin{array}{l}1.509 \text { kb } \\
\text { (127-1726 } \\
\text { gene } \\
\text { fragment) }\end{array}$ & 61 & $\begin{array}{l}\text { Dr. Mark } \\
\text { Felton, } \\
\text { LSHTM }\end{array}$ & His-tag & pPET/ProBond® & Felton (2002) \\
\hline СТ587 & Enolase & $\begin{array}{l}\text { Phosphopyruvate } \\
\text { hydratase } \\
\text { (enolase family; } \\
\text { 45) }\end{array}$ & L2 & $\begin{array}{l}1.274 \text { kb } \\
\text { (full length) }\end{array}$ & 45 & $\begin{array}{l}\text { Prof. Hill } \\
\text { Gaston and } \\
\text { Dr. Jane } \\
\text { Goodall, } \\
\text { University of } \\
\text { Cambridge }\end{array}$ & His-tag & pPET/ProBond® & $\begin{array}{l}\text { Goodall et al. } \\
\text { (2001b) }\end{array}$ \\
\hline CT443 & Omp2 & $\begin{array}{l}\text { Cysteine rich } \\
\text { outer membrane } \\
\text { protein (60) }\end{array}$ & L2 & $\begin{array}{l}1.65 \mathrm{~kb} \\
\text { (700-2350 } \\
\text { gene } \\
\text { fragment) }\end{array}$ & 60 & $\begin{array}{l}\text { Prof. Hill } \\
\text { Gaston and } \\
\text { Dr. Jane } \\
\text { Goodall, } \\
\text { University of } \\
\text { Cambridge }\end{array}$ & His-tag & pPET/ProBond® & $\begin{array}{l}\text { Goodall et al. } \\
\text { (2001a) }\end{array}$ \\
\hline
\end{tabular}

However, when these phenotypic markers of regulatory activity were compared between TT cases and their controls, no statistical difference was found (Figure 3C). As a general trend CD4+CD25+FOXP3+ cells and CD4+GITR+ cells were higher in TT cases to all chlamydial antigens tested (additional data not shown). Similarly, no difference was detected in the frequency of CD4+FOXP3+ or CD4+CD25+ cells between cases and controls. Since no differences in regulatory cells were apparent we also used the CD4+CD25+FOXP3- population as an indicator of effector cell responses and found that the population frequencies of these cells were equivalent between cases and controls stimulated with EBs (Figure 3C).

\section{ACTIVATED LYMPHOCYTES PRODUCE IFN $\gamma$ AND IL-10 IN RESPONSE TO C. TRACHOMATIS ELEMENTARY BODIES}

Whole blood was stimulated as previously described and stained for CD69, a marker of early activation, in addition to CD4, intracellular IFN $\gamma$ and IL-10. Stimulation with EBs showed a marked increase in CD69 expression and a higher frequency of IFN $\gamma$ and IL-10 producing cells. Figure 4A shows the FACS analysis gating procedure used to examine IFN $\gamma$ and IL-10 production from CD4+ T cells and total PBMC. Despite the induction of CD69 on CD4+ cells and the production of IFN $\gamma$ and IL-10, effector T cell responses were not significantly different between cases and controls (Figure 4C).

\section{CD4 + CELLS ARE NOT THE MAJOR IFN $\gamma$ PRODUCING CELLS IN RESPONSE TO STIMULATION WITH C. TRACHOMATIS ELEMENTARY BODIES}

To assess if CD4+ T cells encapsulated the observed increases in the percentage of CD69, IFN $\gamma$, and IL-10 in the total stimulated population of peripheral blood lymphocytes we examined the percentage of each of these in the CD4+ compartment and the total PBMC compartment. We found that on average less than half of the cells that were producing IFN $\gamma$, IL-10, or expressed 
CD69 were also CD4+ (Figure 4B). To establish which cells were responsible for IFN $\gamma$ production we tested PBMC from individuals exposed to ocular infection but without current signs of trachoma. Five individuals were selected from three different age ranges. This strategy was chosen because we had demonstrated that endemic controls had significant responses to EBs above those observed with co-stimulation alone, but that these were not significantly different between case and control participants. Figure 5A shows representative FACS plots and flow diagrams of the gating and staining protocols used. There was some natural variation with age in the total percentage of NK cells (CD3-CD56+ cells) and of CD8+ T cells. The percentage of CD4+ T cells did not appear to vary with age (Figure 5B). We found that in the first $24 \mathrm{~h}$ of in vitro stimulation, EBs induced IFN $\gamma$ in CD4+, CD8+, and NK cells. The percentage of IFN $\gamma$ producing cells in response to stimulation with EB significantly increased with age and adults over 35 years of age demonstrated the highest levels. The percentage of CD4+ IFN $\gamma+$, although increased, did not appear to vary with age and the overall levels were approximately $4 \times$ lower. Interestingly, CD8+ IFN $\gamma+\mathrm{T}$ cells were highest in the first two age groups though the overall levels were lower than those observed for NK (CD3-CD56+) cells (Figure 5C). Further confirmation that EB stimulation resulted in stimulation of NK cells that increased with age was seen by increasing levels of CD107a+ NK cells, whereas CD8+CD107a+ T cells decreased with age or were almost absent. As expected the CD4+ T cells expressed negligible levels of CD107a (Figure 5D). Figures 5C, D further show that stimulation with EB leads to increases in the percentages of both IFN $\gamma$ and CD107a expressing NK cells (up to $40 \%$ of NK cells express CD107a when stimulated by EB in adults over 35 years of age) compared to control cultures with culture medium alone and that in each case the difference and magnitude increases with age.

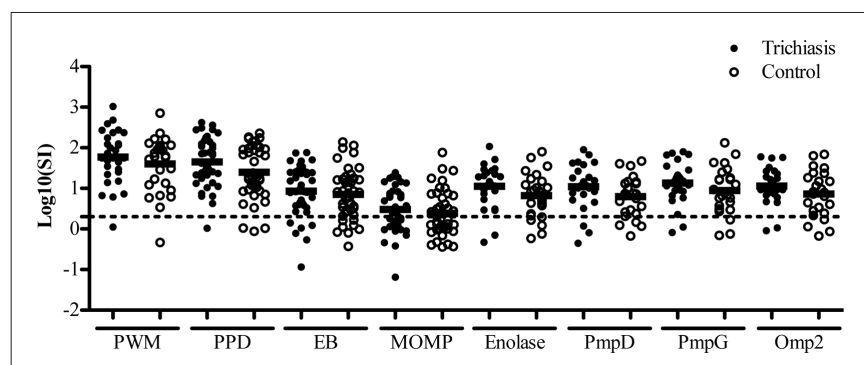

FIGURE 1 |Trachomatous trichiasis cases do not differ in proliferative responses to Chlamydia trachomatis antigens compared to controls. PBMCs $\log _{10}$ stimulation index (test antigen c.p.m/non-stimulated c.p.m) were calculated after 6 days of stimulation with PWM or chlamydial antigens EBs, MOMP, Enolase, PmpD, PmpG, Omp2. Trichiasis cases $(\bullet)$ and disease free endemic controls (०). Paired students $t$-test was performed on each group (up to 42 pairs). The dashed line represents stimulation index $=2$. All responses above this dashed line were considered above background. Each antigen induced a statistically significant response above background. No statistical significance was detected between proliferative responses of the clinical groups to any chlamydial antigen. Analysis based on the proportion of responder $(\mathrm{SI}>2)$ versus non-responder $(\mathrm{SI}<2)$ also found that there were no differences evident between the clinical groups.

\section{DISCUSSION}

Both TT cases and controls had lymphoproliferative responses that were above background when stimulated with EBs, Enolase, PmpD, PmpG, and Omp2 antigens. Responses to some of these antigens have been investigated as putative vaccine candidates (Coler et al., 2009; Goodall et al., 2001a,b) and studied in human infection. More recently, a number of chlamydial antigens such as LcrE (CPn0324/CT089) and chlamydial protease-like activating factor (CPAF/CT858) have been proposed as potential vaccine candidates and their responsiveness has been tested in animals and humans (Olsen et al., 2006, 2007, 2010; Thorpe et al., 2007; Barker et al., 2008; Follmann et al., 2008). Although most of the TT study participants were able to elicit proliferative responses to the chlamydial antigens, the degree of proliferation was not significantly different between individuals with severe scarring disease and controls without disease. As a general trend responses to each antigen were higher in cases with TT, in contrast to our previous findings (Holland et al., 1993, 1996). However, in previous studies higher proportions of individuals with trachomatous scarring were still infected with $C$. trachomatis and were at earlier stages of disease, where C. trachomatis driven fibrotic responses could still be progressing. We also previously found that serum antibody responses in those with trachomatous scarring were higher compared to controls whereas in this cohort C. trachomatis serovar A antibody responses were equal between the groups. This suggested that both groups of individuals had experienced similar levels of exposure to ocular infection and that there had been little recent infection. This changing environment could explain why we did not detect any significant differences compared with our own previous findings (Harding-Esch et al., 2009b).

Although MOMP constitutes up to $60 \%$ of an EB it nevertheless contains a significant proportion of the total antigenic repertoire (Wang et al., 2010). It is the most abundant surface exposed protein of EBs, is highly conserved across C. trachomatis serovars containing a large number of $\mathrm{T}$ cell specific epitopes (Kim and DeMars, 2001; Nunes et al., 2010) and anti-MOMP antibodies have been shown to neutralize C. trachomatis in vitro (Cotter et al., 1995). Because of these properties it has been widely studied as a putative vaccine candidate (Zhang et al., 1997). More recently native MOMP (nMOMP) has been used to immunize monkeys and successfully induced high titers of neutralizing antibodies that reduced the infectious ocular burden within the first 2 weeks of infection. Despite the promising results nMOMP immunization had no lasting effects on the course of clinical disease or burden and duration of infection (Kari et al., 2009). In our experiments MOMP induced only weak responses in the majority of individuals. Antibodies specific to $\mathrm{PmpD}$ have also been shown to neutralize C. trachomatis in vitro regardless of serotype (Crane et al., 2006), and Omp2 has been shown to be recognized by Chlamydiaspecific human CD8+ T cells (Gervassi et al., 2004). PmpG which is part of the outer membrane complex and may be involved in the invasion of the host cell by $C$. trachomatis was also tested. Each of these antigens induced responses but these were not significantly different between cases and controls. Thus far, with the exception of MOMP and hsp60, no other antigens have been evaluated by measuring cell mediated immune responses in individuals with trachoma. Skwor et al. (2010) have tested human tear fluid for 
EB
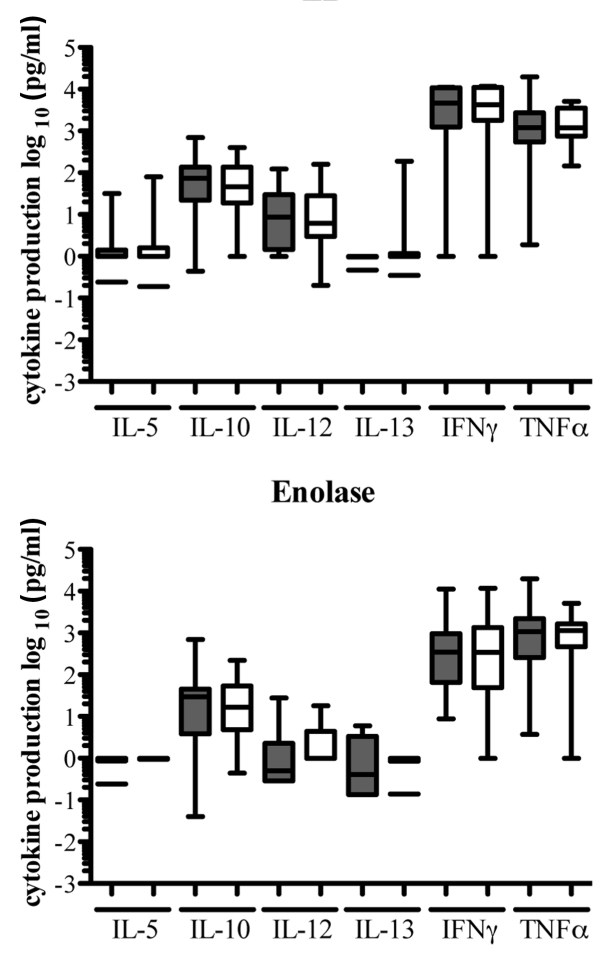

PmpG

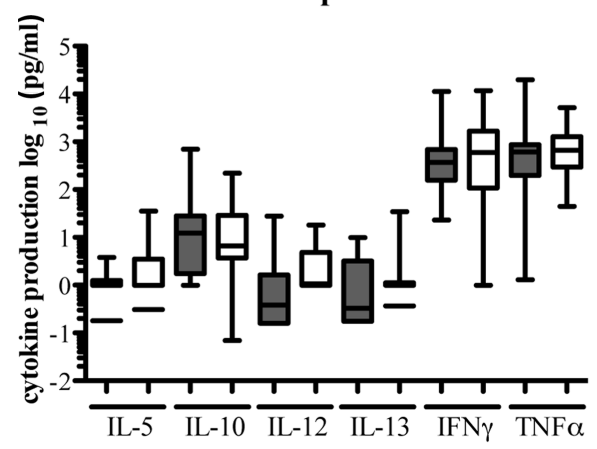

FIGURE 2 | Chlamydial antigens induce cytokine responses that are significantly above responses of cultures in culture medium alone, however, the levels of cytokine production are not statistically different between diseased and non-diseased individuals. Each plot represents IL-5,
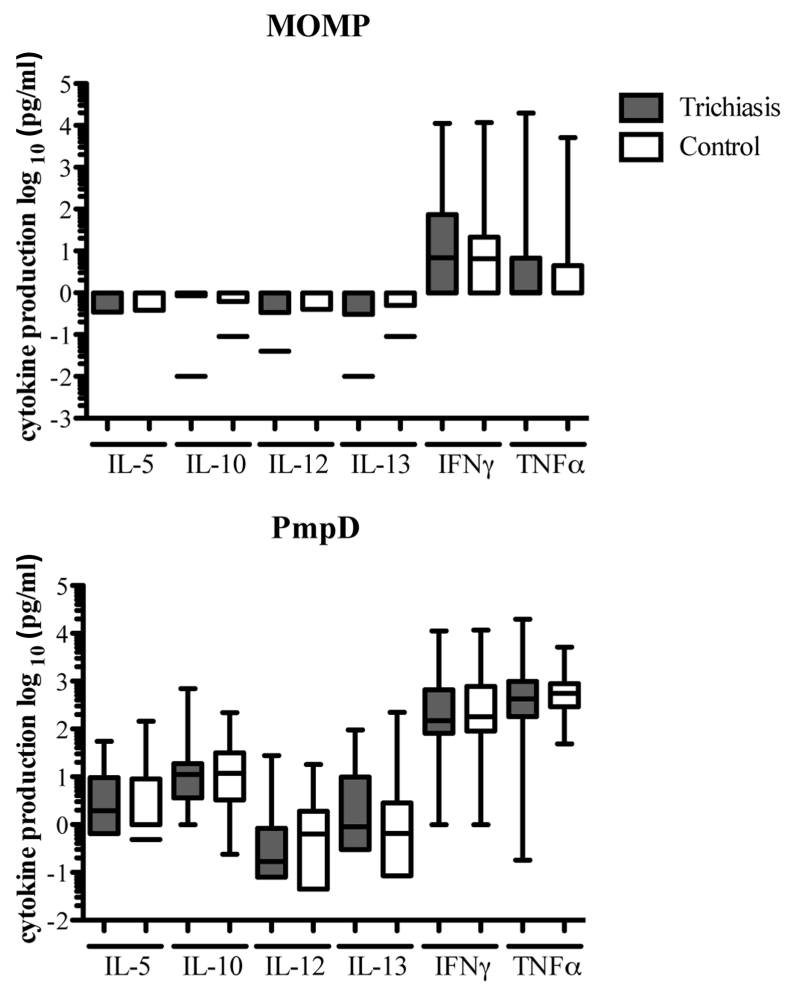

Omp2

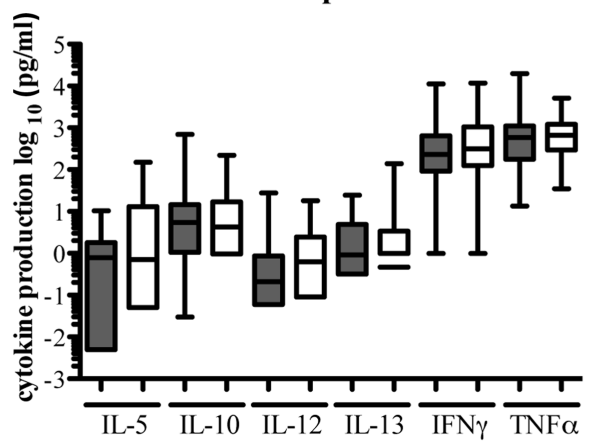

IL-10, IL-12p70, IL-13, IFN $\gamma$ and TNF $\alpha$ production in response to stimulation with CtEBs, MOMP, Enolase, PmpD, PmpG, and Omp2. Responses from TT cases and controls are depicted as shaded and non-shaded box and whisker plots respectively. antibody reactivity to a number of antigens (cHSP60, CPAF, and CT795) and found that IgG responses to CPAF were associated with TT cases and responses to all three antigens were elevated during inflammation, but it remains unclear how this might relate to cellular responses and requires further investigation.

Interleukin-10 and IFN $\gamma$ have been extensively studied in mice and humans with respect to chlamydial infection and IL-10 has been found to be associated with the persistence of infection, while IFN $\gamma$ has been linked to its resolution (reviewed in Yang, 2003). One study using IFN $\gamma$ knockout mice infected with $C$. muridarum found that production of IL-5 was elevated and correlated with more severe disease (Wang et al., 1999). Another study found that when murine dendritic cells were infected with $C$. trachomatis, the subsequent production of IL-12 and TNF $\alpha$ correlated with containment of the bacteria (Knight et al., 1995). Furthermore, studies have shown that mice infected with C. muridarum that received CD11c+ CD8 $\alpha+$ cells had increased amounts of proinflammatory cytokines such as IFN $\gamma$, TNF $\alpha$, and IL-12 and decreased production of the Th 2 cytokines IL-4, IL-5, and IL-13, which correlated with protection against infection. Our results show that in peripheral blood of individuals exposed to C. trachomatis, most chlamydial antigens tested were able to produce above background levels of IL-10, IL-12, IFN $\gamma$, and TNF $\alpha$ cytokines 


\section{A}

Whole blood + CD28/CD49d
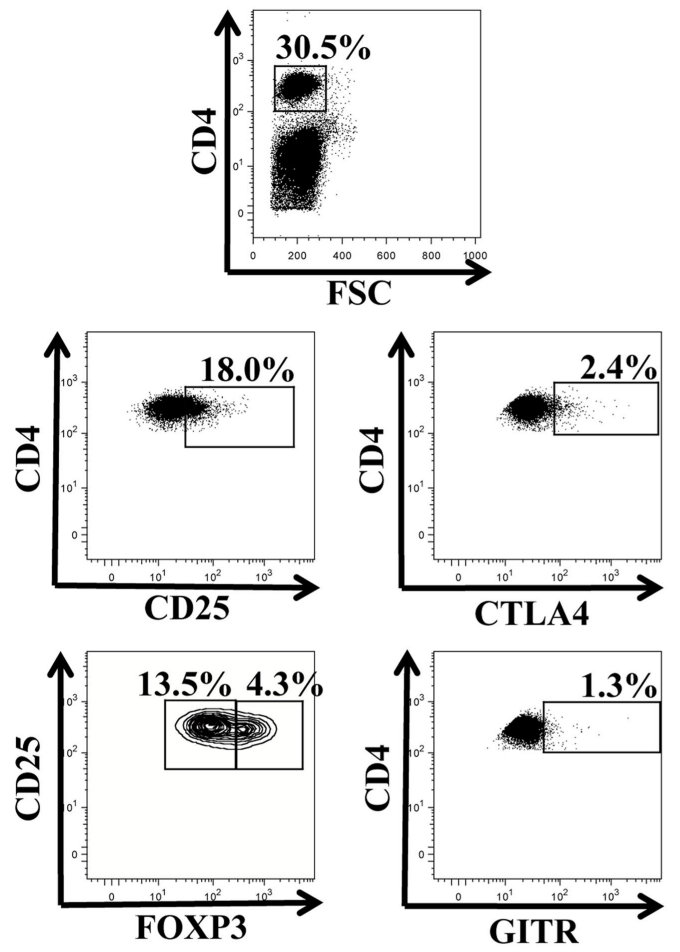

C

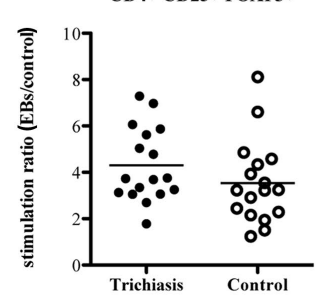

B Whole blood $+C t$ EBs + CD28/CD49d
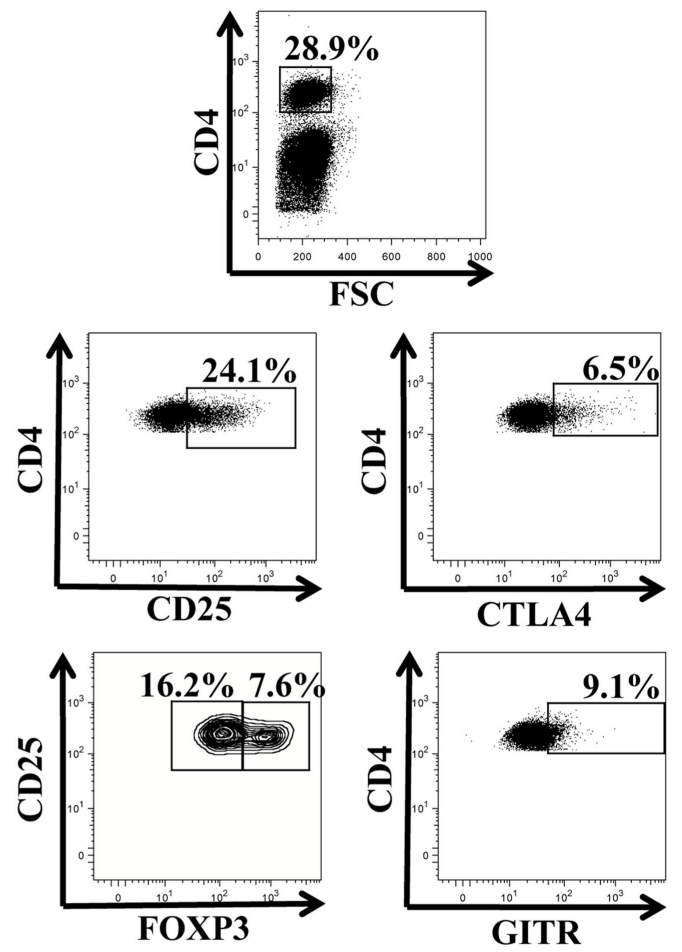

CD4+ CTLA4+

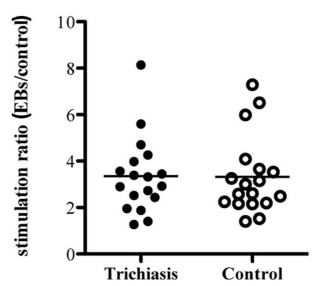

CD4+ GITR+

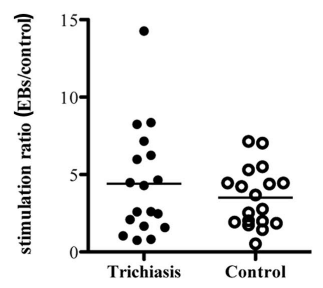

FIGURE 3 | Representative FACS plots of whole blood cultured for $\mathbf{4 8 ~} \mathbf{h}$ with co-stimulatory molecules CD28/CD49d (A) or CD28/CD49d and chlamydial elementary bodies (B) are shown to demonstrate the gating strategy used to enumerate the percentage of Tregs. FOXP3+ cells were gated within the population of CD4+CD25+ cells. The CD25+ population was taken as continuous $\left(C D 25^{\mathrm{hi}}\right.$ and $C D 25^{\circ}$ expressing cells were not differentiated). CD4+ effector cells were identified as the
CD4+CD25+FOXP3- population. (C) Responses of trichiasis cases ( $n=17$ ) and endemic controls $(n=17)$ are represented as a stimulation ratio (i.e., percentage of CD4+CTLA4+ cells induced by EB stimulation/percentage of CD4+CTLA4+ induced by co-stimulation alone). Tregs and CD4+GITR+ cells were higher in trichiasis cases but there were no statistically significant differences between cases and controls in either regulatory or effector T cell populations. after 6 days of culture. Only PmpD and Enolase were able to stimulate IL-5 and IL-13 cytokine responses respectively. However, there were no clear indications that any particular antigen or cytokine profile was significantly different between cases and controls. This suggests that a larger population study is required with follow-up and repeat testing, or that the methods employed in vitro are not sufficiently sensitive to detect differences in these particular cytokines.

Whilst the roles of IL-10 and IFN $\gamma$ have been intensively studied in chlamydial disease, there has been little investigation of regulatory $\mathrm{T}$ cells in mediating the response to $C$. trachomatis. Our results show that Tregs (CD4+CD25+FOXP3+) and the co-stimulatory surface markers with inhibitory or regulatory functions (CTLA4 and GITR) are up-regulated in response to stimulation with chlamydial EBs. We also found higher levels of CD4+CD25+FOXP3+ and CD4+GITR+ T cells in TT cases compared to controls (although these differences were not statistically significant). Other authors have suggested that the CD4+CD25+FOXP3- can also represent an effector population (Burl et al., 2010); whilst these were increased over co-stimulation alone by stimulation with EB, the levels were not significantly different between TT cases and unaffected controls. Interestingly, we found that IFN $\gamma$ produced in response to $C$. trachomatis EB was not exclusive to CD4+ lymphocytes, and the in vitro nature of the stimulation with non-viable EBs would not efficiently favor 
A
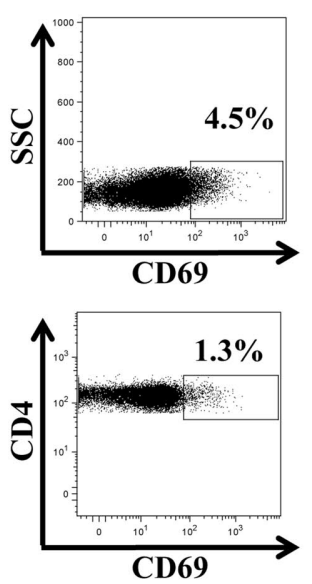

B

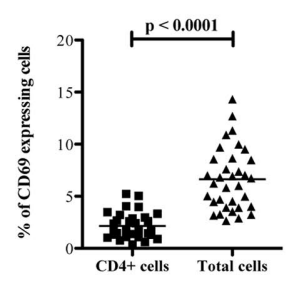

C

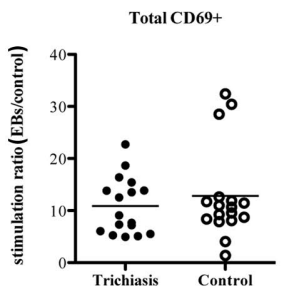

CD4+ CD69+

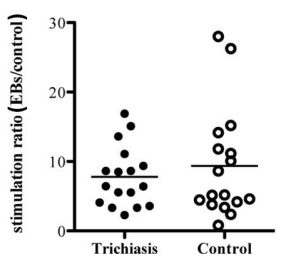

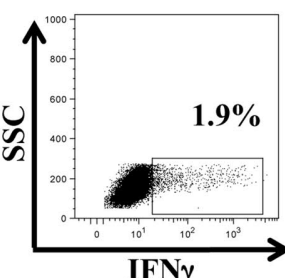

IFN $\gamma$

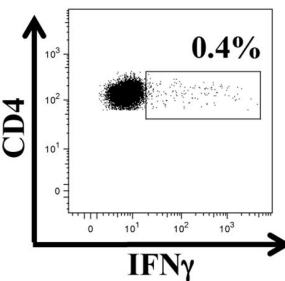

IFN $\gamma$

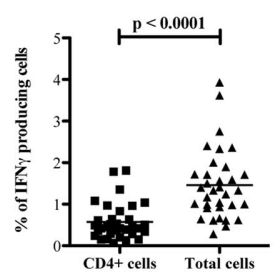

Total IFN $\gamma+$

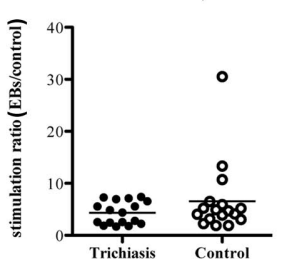

CD4+ IFN $\gamma+$

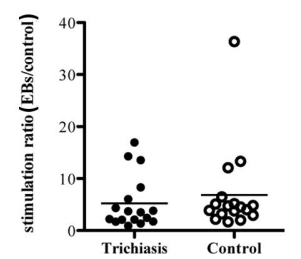

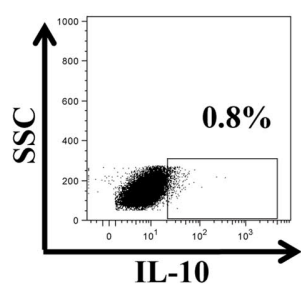
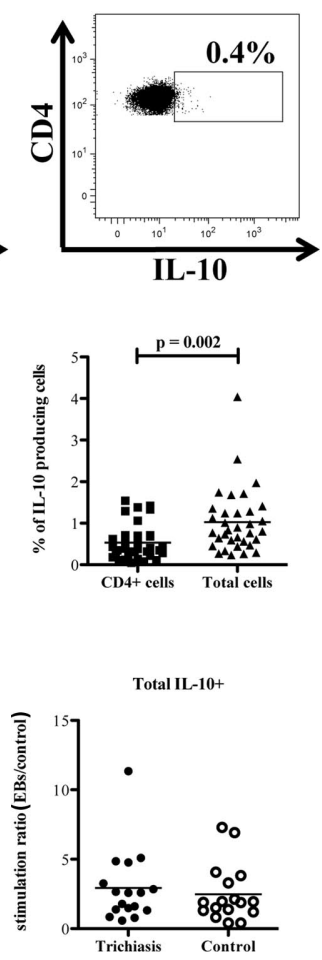

CD4+ IL-10+

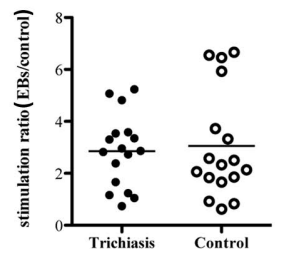

FIGURE 4 | CD4+ cells are not the primary source of IFN $\boldsymbol{\gamma}$ following stimulation with EBs. (A) Representative FACS plots of whole blood cultured for $48 \mathrm{~h}$ with EBs and co-stimulatory CD28/CD49d demonstrate the gating strategy used to distinguish between total and CD4+ IFN $\gamma$ producing cells, as well as total and CD4+ IL-10 producing cells. (B) Percentage of total IFN $\gamma+$, CD69+, and IL-10 producing cells is significantly higher than the percentage of
CD4+ IFN $\gamma+, C D 4+C D 69+$, and CD4+IL-10+ cells in all trichiasis cases and controls $(n=34)$, indicating that CD4+T cells are not the only source of IFN $\gamma$, IL-10, and activated cells. (C) Responses from trichiasis cases $(n=17)$ and controls $(n=17)$ represented as a stimulation ratio (as in Figure 3 ). The ratio of CD4+ activated (CD69+) or IFN $\gamma+/ / L-10+$ cells are slightly higher in the control group but the difference is not significantly different. stimulation of CD8+ T cells. Given that $<50 \%$ of the total IFN $\gamma$ production appeared to be from CD4+ T cells, we investigated using flow cytometry which cells were responsible for the early IFN $\gamma$ production. We found that even with a restricted sample size and therefore statistical power, CD3-CD56+ NK cells were a major source of very early IFN $\gamma$ production (within the first $18 \mathrm{~h}$ of in vitro restimulation). Since the magnitude of this response increased with age and the frequency and duration of trachoma decrease with age (Bailey et al., 1999; Faal et al., 2006), it is possible that these cells play a significant role in ocular disease and infection. Such responses are not unique and are in line with those observed for responses following vaccination or as a result of protozoan or viral infection (Horowitz and Riley, 2010; Horowitz et al., 2010a,b; McCall et al., 2010). Interestingly, in subjects with active trachoma and infection, host gene transcriptional profiles in the conjunctiva suggest a previously unappreciated role for $\mathrm{NK}$ cells (Natividad et al., 2010). These initial in vitro experiments suggest that NK or NK-like cells are rapidly induced by EB and supports the suggestion that lymphocytes other than CD4+ T cells contribute a significant proportion of IFN $\gamma$ in the periphery. EB 
A

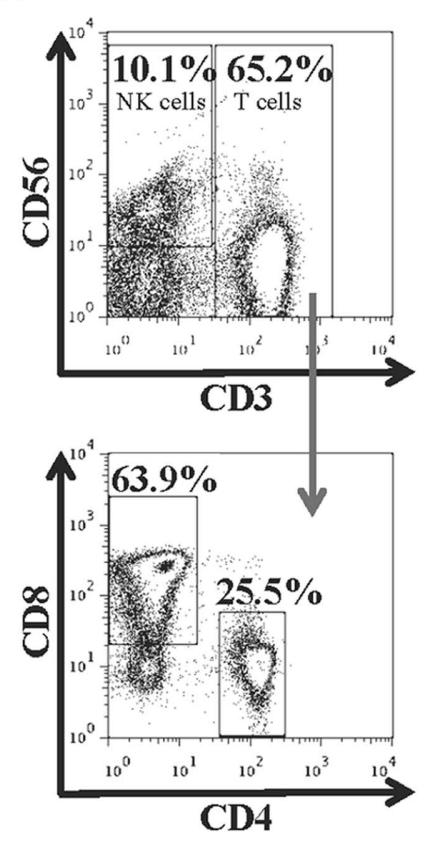

B

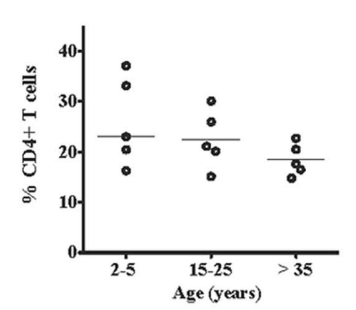

C

D
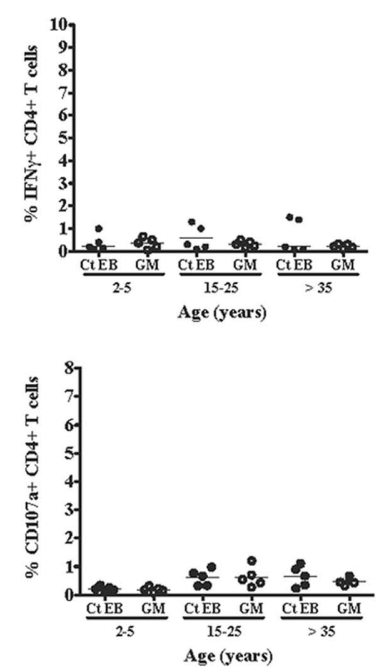

GM
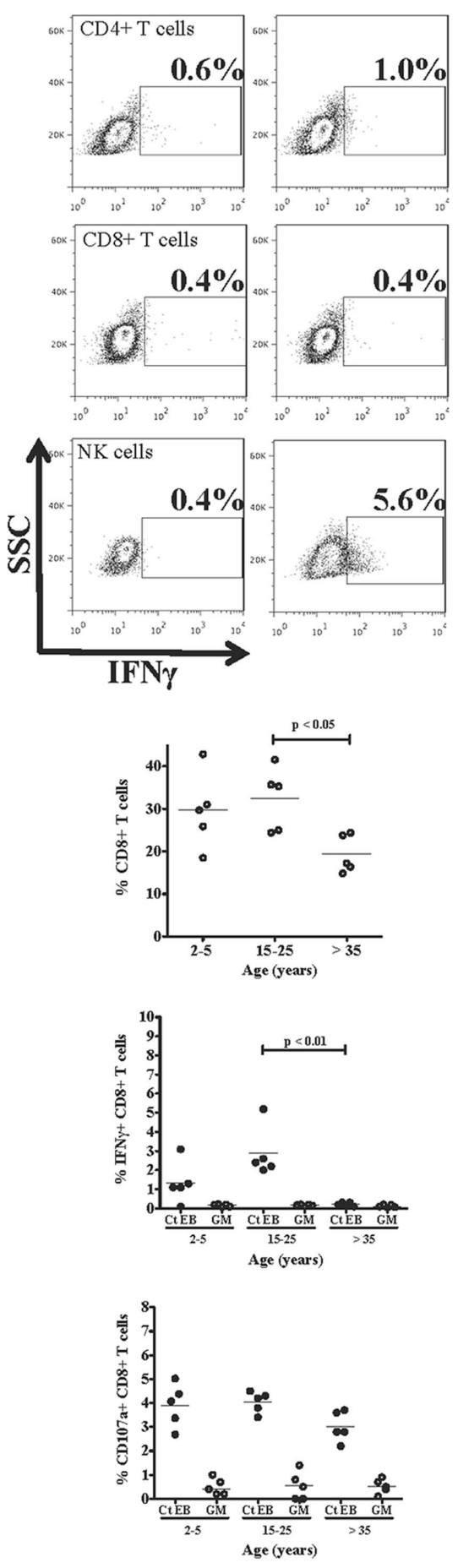

GM

$C t \mathbf{E B}$
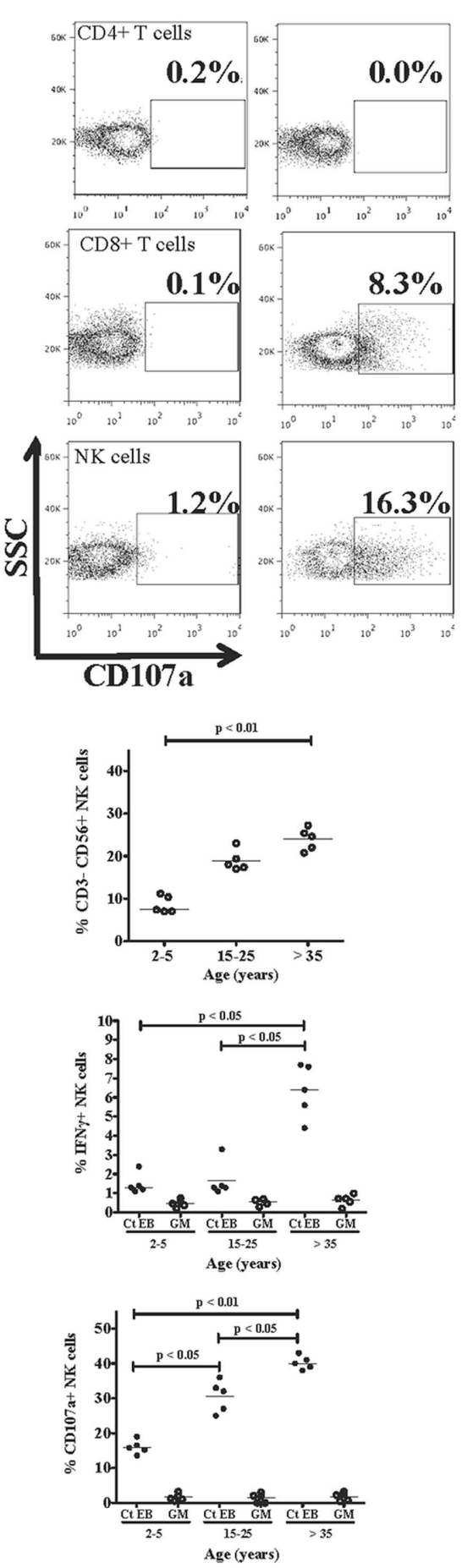

FIGURE 5 | CD3-CD56+ natural killer (NK) cells are a major source of IFN $\gamma$ in response to $E B$ stimulation that increases with age. PBMC from healthy individuals ranging in age from 2 to 5 years $(n=5), 15-25$ years $(n=5)$, and $>35$ years $(n=5)$ were stimulated for $24 \mathrm{~h}$ with EB. (A) Representative FACS plots demonstrate the gating strategy used to define populations of $\mathrm{CD} 4+$ and CD8+T cells and NK cells. NK cells (CD3-CD56+) were gated from CD3+T cells. The CD3+T cells were then further sub-divided based on CD4+ or CD8+ expression. (B) Cell percentages in each age group demonstrate the natural variation of $\mathrm{CD} 8+\mathrm{T}$ and $\mathrm{NK}$ cell levels, whereas $\mathrm{CD} 4+\mathrm{T}$ cell levels do not appear to vary with age. (C) The percentage of NK cells producing IFN $\gamma$ significantly increased with age, while the percentage of CD8+ IFN $\gamma+$ cells significantly decreased in the $>35$ years age group. The percentage of CD4+ IFN $\gamma+$ did not differ among the different age groups. (D) The percentage of CD107a+ NK cells significantly increased with age, whereas levels of CD107a expression in CD8+T cells did not differ with age. CD4+T cells expressed negligible levels of CD107a. 
stimulation also leads to the early activation of other non-CD4+ $\mathrm{T}$ cells along with IL-10 production. We did not investigate the phenotypes of the cells that are activated or produce IL-10 and this warrants further more detailed investigation. Some in vitro studies have suggested that stimulated T cells rapidly acquire CD56 when strongly stimulated through the CD3/TCR complex with additional IL-2 (Kelly-Rogers et al., 2006) and that the phenotypic profile of NK cells is heterogeneous. Since we stained for both surface and internalized CD3 to identify the classical NK cell population (CD3-CD56+; Meier et al., 2005; Titanji et al., 2008; Li et al., 2009; Linn et al., 2009) we exclude this possibility as an in vitro artifact and suggest that the interaction with antigenexperienced $\mathrm{T}$ cells should be investigated further in response to chlamydial infection.

The onset of TT usually occurs well into adulthood and previous studies have revealed that $C$. trachomatis is rarely detected in the conjunctiva at that point (Burton et al., 2007). Intriguingly, TT cases continue to progress toward more severe trichiasis and eventually blindness despite their peripheral immune response being comparable to that of individuals with equal exposure to infection but without the clinical signs or sequelae of trachoma.

\section{REFERENCES}

Anderson, C. F., Oukka, M., Kuchroo, V. J., and Sacks, D. (2007).CD4(+)CD25(-) Foxp3(-) Th1 cells are the source of IL-10-mediated immune suppression in chronic cutaneous leishmaniasis. J. Exp. Med. 204, 285-297.

Bailey, R., Duong, T., Carpenter, R., Whittle, H., and Mabey, D. (1999). The duration of human ocular Chlamydia trachomatis infection is age dependent. Epidemiol. Infect. 123, 479-486.

Bailey, R. L., Holland, M. J., Whittle, H. C., and Mabey, D. C. (1995). Subjects recovering from human ocular chlamydial infection have enhanced lymphoproliferative responses to chlamydial antigens compared with those of persistently diseased controls. Infect. Immun. 63, 389-392.

Barker, C. J., Beagley, K. W., Hafner, L. M., and Timms, P. (2008). In silico identification and in vivo analysis of a novel T-cell antigen from Chlamydia, NrdB. Vaccine 26, 1285-1296.

Belkaid, Y., and Tarbell, K. (2009). Regulatory $\mathrm{T}$ cells in the control of host-microorganism interactions (*). Annu. Rev. Immunol. 27, 551-589.

Bennett, S., and Riley, E. M. (1992). The statistical analysis of data from immunoepidemiological studies. J. Immunol. Methods 146, 229-239.

Burl, S., Adetifa, U. J., Cox, M., Touray, E., Ota, M. O., Marchant, A., Whittle, H., McShane, H., Rowland-Jones, S. L., and Flanagan, K. L. (2010). Delaying bacillus Calmette-Guerin vaccination from birth to $41 / 2$ months of age reduces postvaccination $\mathrm{Th} 1$ and
IL-17 responses but leads to comparable mycobacterial responses at 9 months of age. J. Immunol. 185, 2620-2628.

Burton, M. J., Adegbola, R. A., Kinteh, F., Ikumapayi, U. N., Foster, A., Mabey, D. C., and Bailey, R. L. (2007). Bacterial infection and trachoma in the Gambia: a case control study. Invest. Ophthalmol. Vis. Sci. 48, 4440-4444.

Burton, M. J., Bailey, R. L., Jeffries, D., Mabey, D. C., and Holland, M. J. (2004). Cytokine and fibrogenic gene expression in the conjunctivas of subjects from a Gambian community where trachoma is endemic. Infect. Immun. 72, 7352-7356.

Burton, M. J., Bailey, R. L., Jeffries, D., Rajak, S. N., Adegbola, R. A., Sillah, A., Mabey, D. C., and Holland, M. J. (2010). Conjunctival expression of matrix metalloproteinase and proinflammatory cytokine genes after trichiasis surgery. Invest. Ophthalmol. Vis. Sci. 51, 3583-3590.

Burton, M. J., Rajak, S. N., Bauer, J., Weiss, H. A., Tolbert, S. B., Shoo, A., Habtamu, E., Manjurano, A., Emerson, P. M., Mabey, D. C., Holland, M. J., and Bailey, R. L. (2011). The conjunctival transcriptome in scarring trachoma. Infect. Immun. 79, 499-511.

Chiaramonte, M. G., Mentink-Kane, M., Jacobson, B. A., Cheever, A. W., Whitters, M. J., Goad, M. E., Wong, A., Collins, M., Donaldson, D. D., Grusby, M. J., and Wynn, T. A. (2003). Regulation and function of the interleukin 13 receptor alpha 2 during a T helper cell type 2-dominant

This would suggest that adaptive $\mathrm{T}$ cell memory responses in the periphery do not reflect clinical disease status and that other factors such as innate inflammatory responses involving polymorphs (such as neutrophils) and host epithelial cells, continue to drive fibrosis or recurrent trichiasis. This is supported by several previous studies linking conjunctival gene expression and trichiasis (Burton et al., 2010, 2011; Holland et al., 2010). Other factors such as the compromised ocular surface and secondary bacterial infection also contribute to continued inflammation and disease. Thorough sampling of the immune response at the site of infection and a more in-depth examination of the interaction of adaptive $\mathrm{T}$ cell responses and NK cell responses may help further probe the mechanisms of immunopathogenesis of trachoma.

\section{ACKNOWLEDGMENTS}

The authors thank the ophthalmic nurses of the Gambian National Eye Care Programme and the field staff from the Medical Research Council Laboratories for their hard work and dedication. This study was funded by a grant from the Wellcome Trust $(079246 / \mathrm{Z} / 06 / \mathrm{Z})$ with additional support from the Medical Research Council, UK in The Gambia.

immune response. J. Exp. Med. 197, 687-701.

Cohen, C. R., Koochesfahani, K. M., Meier, A. S., Shen, C., Karunakaran, K., Ondondo, B., Kinyari, T., Mugo, N. R., Nguti, R., and Brunham, R. C. (2005). Immunoepidemiologic profile of Chlamydia trachomatis infection: importance of heat-shock protein 60 and interferon- gamma. J. Infect. Dis. 192, 591-599.

Coler, R. N., Bhatia, A., Maisonneuve, J. F., Probst, P., Barth, B., Ovendale, P., Fang, H., Alderson, M., Lobet, Y., Cohen, J., Mettens, P., and Reed, S. G. (2009). Identification and characterization of novel recombinant vaccine antigens for immunization against genital Chlamydia trachomatis. FEMS Immunol. Med. Microbiol. 55, 258-270.

Cotter, T. W., Meng, Q., Shen, Z. L., Zhang, Y. X., Su, H., and Caldwell, H. D. (1995). Protective efficacy of major outer membrane protein-specific immunoglobulin A (IgA) and IgG monoclonal antibodies in a murine model of Chlamydia trachomatis genital tract infection. Infect. Immun. 63, 4704-4714.

Crane, D. D., Carlson, J. H., Fischer, E. R., Bavoil, P., Hsia, R.C., Tan, C., Kuo, C.C., and Caldwell,H.D. (2006). Chlamydia trachomatis polymorphic membrane protein D is a species-common panneutralizing antigen. Proc. Natl. Acad. Sci. U.S.A. 103, 1894-1899.

Faal, N., Bailey, R. L., Jeffries, D., Joof, H., Sarr, I., Laye, M., Mabey, D. C., and Holland, M. J. (2006). Conjunctival FOXP3 expression in trachoma: do regulatory $\mathrm{T}$ cells have a role in human ocular Chlamydia trachomatis infection? PLoS Med. 3, e266. doi: 10.1371/ journal.pmed.0030266

Felton, M. (2002). Studies of Human Immune Responses to Various Antigenic Proteins of Chlamydia trachomatis. Ph. D. thesis, University of London (LSHTM), London.

Finney, O. C., Riley, E. M., and Walther, M. (2010). Phenotypic analysis of human peripheral blood regulatory $\mathrm{T}$ cells (CD4+FOXP3+CD127lo/-) ex vivo and after in vitro restimulation with malaria antigens. Eur. J. Immunol. 40, 47-60.

Follmann, F., Olsen, A. W., Jensen, K. T., Hansen, P. R., Andersen, P., and Theisen, M. (2008). Antigenic profiling of a Chlamydia trachomatis geneexpression library. J. Infect. Dis. 197, 897-905.

Fontenot, J. D., Rasmussen, J. P., Williams, L. M., Dooley, J. L., Farr, A. G., and Rudensky, A. Y. (2005). Regulatory $\mathrm{T}$ cell lineage specification by the forkhead transcription factor foxp 3 . Immunity 22, 329-341.

Gervassi, A. L., Grabstein, K. H., Probst, P., Hess, B., Alderson, M. R., and Fling, S. P. (2004). Human CD8+ T cells recognize the $60-\mathrm{kDa}$ cysteinerich outer membrane protein from Chlamydia trachomatis. J. Immunol. 173, 6905-6913.

Gondek, D. C., Roan, N. R., and Starnbach, M. N. (2009). T cell responses in the absence of IFN-gamma exacerbate uterine infection with Chlamydia trachomatis. J. Immunol. 183, 1313-1319. 
Goodall, J. C., Beacock-Sharp, H., Deane, K. H., and Gaston, J. S. (2001a). Recognition of the 60 kilodalton cysteine-rich outer membrane protein OMP2 by CD4(+) T cells from humans infected with Chlamydia trachomatis. Clin. Exp. Immunol. 126, 488-493.

Goodall, J. C., Yeo, G., Huang, M., Raggiaschi, R., and Gaston, J. S. (2001b). Identification of Chlamydia trachomatis antigens recognized by human CD4+ T lymphocytes by screening an expression library. Eur. J. Immunol. 31, 1513-1522.

Grossman, W. J., Verbsky, J. W., Barchet, W., Colonna, M., Atkinson, J. P., and Ley, T. J. (2004). Human T regulatory cells can use the perforin pathway to cause autologous target cell death. Immunity 21, 589-601.

Harding-Esch, E. M., Edwards, T., Sillah, A., Sarr, I., Roberts, C. H., Snell, P., Aryee, E., Molina, S., Holland, M. J., Mabey, D. C. W., and Bailey, R. L. (2009a). Active trachoma and ocular Chlamydia trachomatisinfection in the Gambia: on course for elimination by 2020? PLoS Negl. Trop. Dis.3, e573. doi: 10.1371/journal.pntd.0000573

Harding-Esch, E. M., Edwards, T., Sillah, A., Sarr, I., Roberts, C. H., Snell, P., Aryee, E., Molina, S., Holland, M. J., Mabey, D. C. W., and Bailey, R. L. (2009b). Active trachoma and ocular Chlamydia trachomatis infection in two Gambian regions: on course for elimination by 2020? PLoS Negl. Trop. Dis. 3, e573. doi: 10.1371/journal. pntd.0000573

Holland, M. J., Bailey, R. L., Conway, D. J., Culley, F., Miranpuri, G., Byrne, G. I., Whittle, H.C., and Mabey, D. C. (1996). Thelper type-1 (Th1)/Th2 profiles of peripheral blood mononuclear cells (PBMC); responses to antigens of Chlamydia trachomatis in subjects with severe trachomatous scarring. Clin. Exp. Immunol. 105, 429-435.

Holland, M. J., Bailey, R. L., Hayes, L. J., Whittle, H. C., and Mabey, D. C. (1993). Conjunctival scarring in trachoma is associated with depressed cell- mediated immune responses to chlamydial antigens. J. Infect. Dis. 168, 1528-1531.

Holland, M. J., Jeffries, D., Pattison, M., Korr, G., Gall, A., Joof, H., Manjang, A., Burton, M. J., Mabey, D. C., and Bailey, R. L. (2010). Pathway-focused arrays reveal increased matrix metalloproteinase-7 (matrilysin) transcription in trachomatous trichiasis. Invest. Ophthalmol. Vis. Sci. 51, 3893-3902.

Hori, S., Nomura, T., and Sakaguchi, S. (2003). Control of regulatory T cell development by the transcription factor Foxp3. Science 299, 1057-1061.
Horowitz, A., Behrens, R. H., Okell, L., Fooks, A. R., and Riley, E. M. (2010a). NK cells as effectors of acquired immune responses: effector CD4+ T cell-dependent activation of NK cells following vaccination. J. Immunol. 185, 2808-2818.

Horowitz, A., Newman, K. C., Evans, J. H., Korbel, D. S., Davis, D.M., and Riley, E. M. (2010b). Cross-talk between T cells and NK cells generates rapid effector responses to Plasmodium falciparuminfected erythrocytes. J. Immunol. 184, 6043-6052.

Horowitz, A., and Riley, E. M. (2010). Activation of human NK cells by malaria-infected red blood cells. Methods Mol. Biol. 612, 429-446.

Igietseme, J. U., He, Q., Joseph, K., Eko, F. O., Lyn, D., Ananaba, G., Campbell, A., Bandea, C., and Black, C. M. (2009). Role of T lymphocytes in the pathogenesis of Chlamydia disease. J. Infect. Dis. 200, 926-934.

Jankovic, D., Kullberg, M. C., Feng, C. G., Goldszmid, R.S., Collazo, C.M., Wilson, M., Wynn, T. A., Kamanaka, M., Flavell, R. A., and Sher, A. (2007). Conventional T-bet(+)Foxp3(-) Th1 cells are the major source of host-protective regulatory IL-10 during intracellular protozoan infection. J. Exp. Med. 204, 273-283.

Jiang, H., and Chess, L. (2004). An integrated view of suppressor T cell subsets in immunoregulation. J. Clin. Invest. 114, 1198-1208.

Kari, L., Whitmire, W. M., Crane, D. D., Reveneau, N., Carlson, J. H., Goheen, M. M., Peterson, E. M., Pal, S., de la Maza, L. M., and Caldwell, H. D. (2009). Chlamydia trachomatis native major outer membrane protein induces partial protection in nonhuman primates: implication for a trachoma transmissionblocking vaccine. J. Immunol. 182, 8063-8070.

Kelly-Rogers, J., Madrigal-Estebas, L., O'Connor, T., and Doherty, D. G. (2006). Activation-induced expression of CD56 by $\mathrm{T}$ cells is associated with a reprogramming of cytolytic activity and cytokine secretion profile in vitro. Hum. Immunol. 67, 863-873.

Kim, S. K., and DeMars, R. (2001). Epitope clusters in the major outer membrane protein of Chlamydia trachomatis. Curr. Opin. Immunol. 13, 429-436.

Knight, S. C., Iqball, S., Woods, C., Stagg, A., Ward, M.E., and Tuffrey, M. (1995). A peptide of Chlamydia trachomatis shown to be a primary T-cell epitope in vitro induces cell-mediated immunity in vivo. Immunology 85, 8-15.

Li, W., Janowicz, D. M., Fortney, K. R., Katz, B. P., and Spinola, S. M. (2009). Mechanism of human natural killer cell activation by Haemophilus ducreyi. J. Infect. Dis. 200, 590-598.
Linn, Y. C., Lau, S. K., Liu, B. H., Ng, L. H., Yong, H. X., and Hui, K. M. (2009). Characterization of the recognition and functional heterogeneity exhibited by cytokine-induced killer cell subsets against acute myeloid leukaemia target cell. Immunology 126, 423-435.

Mabey, D. C., Solomon, A. W., and Foster A. (2003). Trachoma. Lancet 362, 223-229.

Maloy, K. J., and Powrie, F. (2001) Regulatory $\mathrm{T}$ cells in the control of immune pathology. Nat. Immunol. 2, 816-822.

Mariotti, S. P., Pascolini, D., and RoseNussbaumer, J. (2009). Trachoma: global magnitude of a preventable cause of blindness. Br. J. Ophthalmol. 93, 563-568.

McCall, M. B., Roestenberg, M., Ploemen, I., Teirlinck, A., Hopman, J., de Mast, Q., Dolo, A., Doumbo, O. K., Luty, A., van der Ven, A. J., Hermsen, C. C., and Sauerwein, R.W. (2010). Memory-like IFN-gamma response by NK cells following malaria infection reveals the crucial role of T cells in NK cell activation by P. falciparum. Eur. J. Immunol. 40, 3472-3477.

McGuirk, P., McCann, C., and Mills, K.H. (2002). Pathogen-specific T regulatory 1 cells induced in the respiratory tract by a bacterial molecule that stimulates interleukin 10 production by dendritic cells: a novel strategy for evasion of protective $\mathrm{T}$ helper type 1 responses by Bordetella pertussis. J. Exp. Med. 195, 221-231.

Meier, U.C., Owen, R. E., Taylor, E., Worth, A., Naoumov, N., Willberg, C., Tang, K., Newton, P., Pellegrino, P., Williams, I., Klenerman, P., and Borrow, P. (2005). Shared alterations in NK cell frequency, phenotype, and function in chronic human immunodeficiency virus and hepatitis $\mathrm{C}$ virus infections. J. Virol. 79, 12365-12374.

Natividad, A., Freeman, T. C., Jeffries, D. Burton, M. J., Mabey, D. C., Bailey, R. L., and Holland, M. J. (2010). Human conjunctival transcriptome analysis reveals the prominence of innate defense in Chlamydia trachomatis infection. Infect. Immun. 78, 4895-4911.

Natividad,A.,Holland,M.J., Rockett, K.A., Forton, J., Faal, N., Joof, H. M., Mabey, D. C., Bailey, R. L., and Kwiatkowski, D. P. (2008). Susceptibility to sequelae of human ocular chlamydial infection associated with allelic variation in IL10 cis-regulation. Hum. Mol. Genet. 17, 323-329.

Natividad, A., Wilson, J., Koch, O., Holland, M. J., Rockett, K., Faal, N., Jallow, O., Joof, H. M., Burton, M. J., Alexander, N. D., Kwiatkowski, D. P., Mabey, D. C., and Bailey, R. L. (2005). Risk of trachomatous scarring and trichiasis in Gambians varies with SNP haplotypes at the interferon-gamma and interleukin-10 loci. Genes Immun. 6, 332-340.

Nesburn, A. B., Bettahi, I., Dasgupta, G., Chentoufi, A. A., Zhang, X., You, S., Morishige, N., Wahlert, A. J., Brown, D. J., Jester, J. V., Wechsler, S. L., and BenMohamed, L. (2007). Functional Foxp3+CD4+CD25(bright+) "natural" regulatory $\mathrm{T}$ cells are abundant in rabbit conjunctiva and suppress virus-specific $\mathrm{CD} 4+$ and $\mathrm{CD} 8+$ effector $\mathrm{T}$ cells during ocular herpes infection. J. Virol. 81, 7647-7661.

Nocentini, G., and Riccardi, C. (2005). GITR: a multifaceted regulator of immunity belonging to the tumor necrosis factor receptor superfamily. Eur. J. Immunol. 35, 1016-1022.

Nunes, A., Nogueira, P. J., Borrego, M. J., and Gomes, J. P. (2010). Adaptive evolution of the Chlamydia trachomatis dominant antigen reveals distinct evolutionary scenarios for B- and T-cell epitopes: worldwide survey. PLoS ONE 5, e13171. doi: 10.1371/journal. pone. 0013171

Olsen, A. W., Follmann, F., Hojrup, P., Leah, R., Sand, C., Andersen, P., and Theisen, M. (2007). Identification of human $\mathrm{T}$ cell targets recognized during Chlamydia trachomatis genital infection. J. Infect. Dis. 196, 1546-1552.

Olsen, A. W., Follmann, F., Jensen, K., Hojrup, P., Leah, R., Sorensen, H., Hoffmann, S., Andersen, P., and Theisen, M. (2006). Identification of CT521 as a frequent target of Th1 cells in patients with urogenital Chlamydia trachomatis infection. J. Infect. Dis. 194, 1258-1266.

Olsen, A. W., Theisen, M., Christensen, D., Follmann, F., and Andersen, P. (2010). Protection against Chlamydia promoted by a subunit vaccine (CTH1) compared with a primary intranasal infection in a mouse genital challenge model. PLoS ONE 5, e10768. doi: 10.1371/journal.pone.0010768

Rockey, D. D., Wang, J., Lei, L., and Zhong, G. (2009). Chlamydia vaccine candidates and tools for chlamydial antigen discovery. Expert Rev. Vaccines 8, 1365-1377.

Skwor, T., Kandel, R. P., Basravi, S., Khan, A., Sharma, B., and Dean, D. (2010). Characterization of humoral immune responses to chlamydial heat shock protein 60 , protease-like activity factor and hypothetical protein CT795 in inflammatory and severe trachoma. Invest. Ophthalmol. Vis. Sci. 51, 5128-5136.

Stock, P., Akbari, O., Berry, G., Freeman, G. J., Dekruyff, R. H., and Umetsu, D. T. (2004). Induction of T helper type 1-like regulatory cells that express 
Foxp3 and protect against airway hyper-reactivity. Nat. Immunol. 5, 1149-1156.

Suvas, S., Azkur, A. K., Kim, B. S., Kumaraguru, U., and Rouse, B. T. (2004). CD4(+)CD25(+) regulatory $\mathrm{T}$ cells control the severity of viral immunoinflammatory lesions. J. Immunol. 172, 4123-4132.

Thorpe, C., Edwards, L., Snelgrove, R., Finco, O., Rae, A., Grandi, G., Guilio, R., and Hussell, T. (2007). Discovery of a vaccine antigen that protects mice from Chlamydia pneumoniae infection. Vaccine 25, 2252-2260.

Titanji, K., Sammicheli, S., De Milito, A., Mantegani, P., Fortis, C., Berg, L., Kärre, K., Travi, G., Tassandin, C., Lopalco, L., Rethi, B., Tambussi, G., and Chiodi, F. (2008). Altered distribution of natural killer cell subsets identified by CD56, CD27 and CD70 in primary and chronic human immunodeficiency virus-1 infection. Immunology 123, 164-170.

Vieira, P. L., Christensen, J. R., Minaee, S., O’Neill, E. J., Barrat, F. J., Boonstra, A., Barthlott, T., Stockinger, B., Wraith, D. C., and O'Garra, A. (2004). IL-10secreting regulatory $\mathrm{T}$ cells do not express Foxp3 but have comparable regulatory function to naturally occurring CD4+CD25+ regulatory $\mathrm{T}$ cells. J. Immunol. 172, 5986-5993.

Wang, C., Tang, J., Geisler, W.M., CrowleyNowick, P. A., Wilson, C. M., and Kaslow, R.A. (2005). Human leukocyte antigen and cytokine gene variants as predictors of recurrent Chlamydia trachomatis infection in high-risk adolescents. J. Infect. Dis. 191, 1084-1092.

Wang, J., Chen, L., Chen, F., Zhang, X., Zhang, Y., Baseman, J., Perdue, S., Yeh, I. T., Shain, R., Holland, M., Bailey, R., Mabey, D., Yu, P., and Zhong, G. (2009). A chlamydial type III-secreted effector protein (Tarp) is predominantly recognized by antibodies from humans infected with Chlamydia trachomatis and induces protective immunity against upper genital tract pathologies in mice. Vaccine 27, 2967-2980.

Wang, J., Zhang, Y., Lu, C., Lei, L., Yu, P., and Zhong, G. (2010). A genome-wide profiling of the humoral immune response to Chlamydia trachomatis infection reveals vaccine candidate antigens expressed in humans. J. Immunol. 185, 1670-1680.

Wang, S., Fan, Y., Brunham, R. C., and Yang, X. (1999). IFN-gamma knockout mice show Th2-associated delayed-type hypersensitivity and the inflammatory cells fail to localize and control chlamydial infection. Eur. J. Immunol. 29, 3782-3792.

WHO. (2007). Sexually Transmitted Diseases: Chlamydia trachomatis. Geneva: WHO.

Wynn, T. A. (2004). Fibrotic disease and the $\mathrm{T}(\mathrm{H}) 1 / \mathrm{T}(\mathrm{H}) 2$ paradigm. Nat. Rev. Immunol. 4, 583-594.

Yang, X. (2003). Role of cytokines in Chlamydia trachomatis protective immunity and immunopathology. Curr. Pharm. Des. 9, 67-73.

Yang, X., Gartner, J., Zhu, L., Wang, S., and Brunham, R. C. (1999). IL-10 gene knockout mice show enhanced Th1-like protective immunity and absent granuloma formation following Chlamydia trachomatislung infection. J. Immunol. 162, 1010-1017.

Zhang, D., Yang, X., Berry, J., Shen, C., McClarty, G., and Brunham, R. C. (1997). DNA vaccination with the major outer-membrane protein gene induces acquired immunity to Chlamydia trachomatis (mouse pneumonitis) infection. J. Infect. Dis. 176, 1035-1040.

Zheng, X., Gao, J. X., Chang, X., Wang, Y., Liu, Y., Wen, J., Zhang, H., Zhang, J., and Zheng, P. (2004). B7-CD28 interaction promotes proliferation and survival but suppresses differentiation of
CD4-CD8- T cells in the thymus. J. Immunol. 173, 2253-2261.

Conflict of Interest Statement: The authors declare that the research was conducted in the absence of any commercial or financial relationships that could be construed as a potential conflict of interest.

Received: 29 October 2010; paper pending published: 12 December 2010; accepted: 18 January 2011; published online: 10 February 2011.

Citation: Gall A, Horowitz A, Joof $H$, Natividad A, Tetteh K, Riley E, Bailey RL, Mabey DCW and Holland MJ (2011) Systemic effector and regulatory immune responses to chlamydial antigens in trachomatous trichiasis. Front. Microbio. 2:10. doi: 10.3389/fmicb.2011.00010

This article was submitted to Frontiers in Cellular and Infection Microbiology, a specialty of Frontiers in Microbiology.

Copyright () 2011 Gall, Horowitz, Joof, Natividad, Tetteh, Riley, Bailey, Mabey and Holland. This is an open-access article subject to an exclusive license agreement between the authors and Frontiers Media SA, which permits unrestricted use, distribution, and reproduction in any medium, provided the original authors and source are credited. 